\title{
Patients with rheumatoid arthritis and osteoarthritis in terms of sex hormone receptors and histopathological comparison of features
}

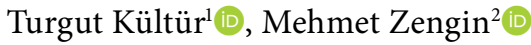 \\ ${ }^{1}$ Department of Physical Medicine and Rehabilitation, Kırıkkale University Faculty of Medicine, Kirıkkale, Turkey \\ ${ }^{2}$ Department of Pathology, Kırıkkale University Faculty of Medicine, Kırıkkale, Turkey
}

\begin{abstract}
Objectives: This study aims to investigate the relationship between estrogen receptors (ERs) and progesterone receptors (PRs) and histopathological findings in synovial tissue in rheumatoid arthritis (RA) and osteoarthritis (OA) patients.

Patients and methods: Synovial tissue samples obtained from synovial surgery from 30 RA (10 males, 20 females) and 92 OA ( 27 males, 65 females) patients with median age of 59 (range, 50 to 67 ) years were analyzed retrospectively between January 2010 and January 2019 . The relationship between histopathological features and hormone receptor presence was analyzed.

Results: There was a meaningful relationship between histopathological parameters and RA and OA ( $p=0.01$ ). The sex hormone receptor's presence was significantly higher in females with RA $(p=0.01)$. Additionally, in the RA group, there was a remarkable relationship between ER and focal aggregates of lymphocytes $(p=0.01)$, perivascular infiltrates of lymphocytes $(p=0.03)$, and diffuse infiltrates of lymphocytes $(p=0.01)$. In the OA group, a significant relationship was observed between PR and subchondral inflammation ( $p=0.01)$. In multivariate analysis, it was observed that ER was an independent risk factor for focal aggregates of lymphocytes in RA group (odds ratio [OR] $=1.51$ [1.02-2.25], $p=0.04$ ). Besides, PR was found to be an independent risk factor for subchondral inflammation in OA group (OR=3.90 [1.28-11.80], $p=0.02)$.

Conclusion: The presence of the sex hormone receptor in the synovium may change histopathological features and affect the clinical course. Keywords: Estrogen receptors, histopathological findings, osteoarthritis, progesterone receptors, rheumatoid arthritis.
\end{abstract}

Osteoarthritis (OA) is a progressive degenerative joint pathology. Rheumatoid arthritis (RA) is an autoimmune disorder that may exhibit systemic involvements besides joints. ${ }^{1}$ In both diseases, various histopathological changes develop with the effect of different mechanisms for damage or repair in synovial tissues., ${ }^{1,2}$ These changes have quite different features for $\mathrm{OA}$ and RA. Although the etiopathogenetic features are not fully enlightened, these two diseases have very different features. The common point of these diseases is that both are seen as more frequently and more severely in females. ${ }^{1,2}$ Sex steroids may produce opposite effects that increase or suppress inflammation through different mechanisms. While estrogen increases the humoral immune response, progesterone suppresses. On the other hand, these two hormones have anti-inflammatory effects by some cytokines. ${ }^{3,4}$ Estrogen receptors (ERs) and progesterone receptors (PRs) are classified in the group of nuclear hormone receptors. ${ }^{5}$ These receptors are ligand-dependent transcription factors found in the cytosol. ${ }^{5}$ Also, ERs and PRs have non-genomic effects, independent of

Received: July 12, 2020 Accepted: July 29, 2020 Published online: January 14, 2021

Correspondence: Turgut Kültür, MD. Kırıkkale Üniversitesi Tıp Fakültesi Fiziksel Tıp ve Rehabilitasyon Anabilim Dalı, Kırıkkale, Türkiye. Tel: +90 318 - 2444697 e-mail: kurgut@hotmail.com

Citation:

Kültür T, Zengin M. Patients with rheumatoid arthritis and osteoarthritis in terms of sex hormone receptors and histopathological comparison of features. Arch Rheumatol 2021;36(2):192-200. 
hormone transcription. This complicates their role in inflammatory diseases. ER and PR expressions have been shown in synovial tissues in RA. ${ }^{5}$ The positive or negative effect of sex hormones in these diseases may be determined by the expression of their receptors in the synovial tissue. In this context, it may be thought that there may be a relationship between histopathological features and the presence of sex hormone receptors for $\mathrm{OA}$ and RA. Sex hormones and receptors in autoimmune and degenerative diseases have been investigated by many authors. However, we could not find any study investigating the relationship between the presence of sex hormone receptors and histopathological findings. Clarification of the protective and destructive aspects of this relationship may contribute to estimating the prognosis, determining the type of treatment, and predicting the response to the drugs. In this study, we aimed to investigate the relationship between ERs and PRs and histopathological findings in synovial tissue in RA and OA patients.

\section{PATIENTS AND METHODS}

A total of $30 \mathrm{RA}$ (10 males, 20 females) and 92 OA (27 males, 65 females) patients with median age of 59 (range, 50 to 67) years who underwent biopsy for ERs and PRs were included in this retrospective study carried out in the Departments of Physical Therapy and Pathology of the Kirıkkale University School of Medicine between January 2010 and January
2019. Patients with a chronic disease that may affect articular cartilage were excluded. Flow chart of the study was presented in Figure 1. The study protocol was approved by the Kirikkale University Faculty of Medicine Ethics Committee (Date: 24.07.2019; no: 2019.06.29). A written informed consent was obtained from each patient. The study was conducted in accordance with the principles of the Declaration of Helsinki.

The clinical information of the patients was noted from the archive records, and the following parameters were recorded from the hematoxylin and eosin (H-E) sections: synoviocyte hyperplasia, fibrosis, proliferating blood vessels, focal aggregates of lymphocytes, perivascular infiltrates of lymphocytes, and diffuse infiltrates of lymphocytes, chondroid-osteoid metaplasia, fibrillation, cartilage degeneration, thickened trabeculae, and subchondral inflammation.

Paraffin-embedded biopsy specimens stored at room temperature were taken from the archive of the Department of Pathology. The available blocks ranged from one to four per patient. One of the most suitable biopsy samples was chosen. When choosing the block, care was taken to leave enough tissue for future studies. Three 4-micron thick sections were taken from these blocks. One was stained with $\mathrm{H}-\mathrm{E}$, while the other two were stained with ER and PR.

Biopsy samples were examined with $\times 10-\times 20$ objectives using a conventional microscope (Nikon Eclipse E600, Nikon AG, Egg, Zurich,
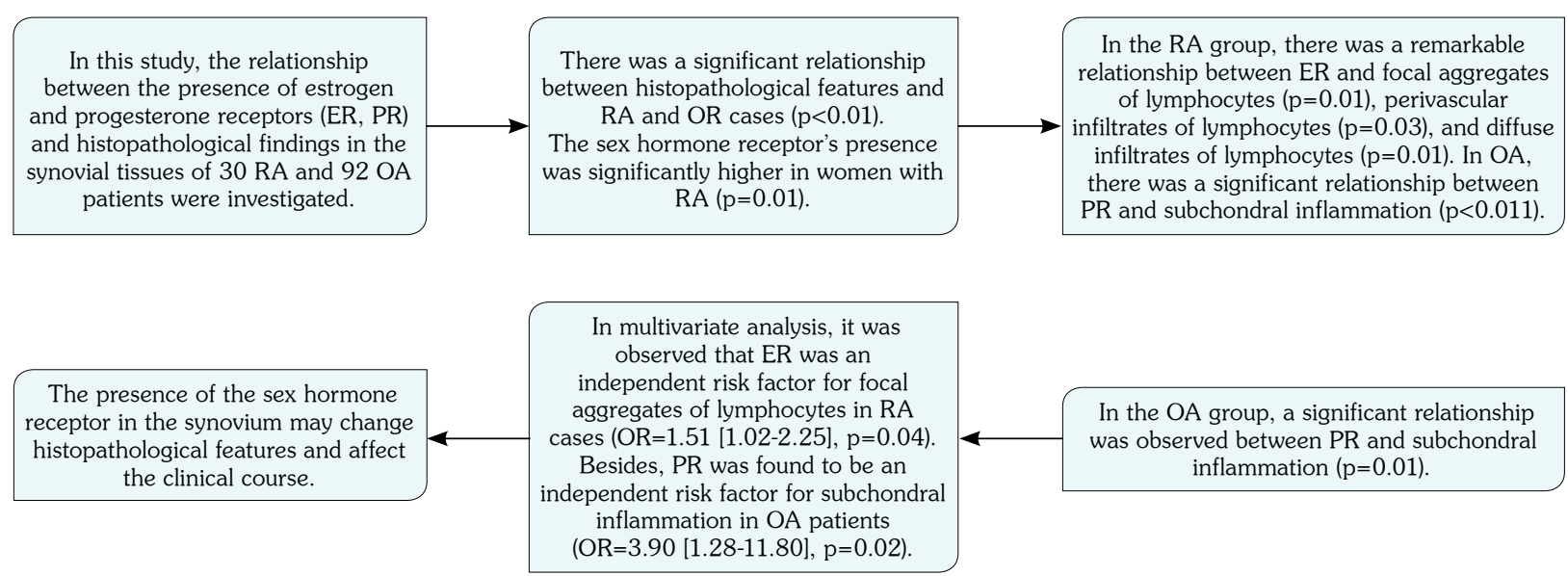

Figure 1. Flowchart of study.

ER: Estrogen receptor; PR: Progesterone receptor; RA: Rheumatoid arthritis; OA: Osteoarthritis; OR: Odds ratio 
Switzerland). The evaluation was performed by an experienced pathologist who was unaware of the clinical diagnosis. Rooney score was used to evaluate histopathological features in RA. ${ }^{6}$ This score consists of the following six items: synoviocyte hyperplasia, fibrosis, proliferating blood vessels, focal aggregates of lymphocytes, perivascular infiltrates of lymphocytes, and diffuse infiltrates of lymphocytes. ${ }^{6}$ The following parameters were used for histopathological features in OA:7 chondroid-osteoid metaplasia, fibrillation, cartilage degeneration, thickened trabeculae, and subchondral inflammation. RA parameters were scored according to Rooney. In this scoring, the parameters are scored between 0 and 10. A high score indicates that the level of synovial inflammation is high. Histopathological findings and receptor status of $\mathrm{OA}$ were recorded as negative-positive. The relationship between the presence of hormone receptors and histopathological findings was investigated (Figure 2).
Antigen recovery was performed after deparaffinization and rehydration for the immunohistochemical study. Sections were then cooled to room temperature and incubated in $0.3 \%$ hydrogen peroxide-methanol solution. Mouse monoclonal ER (Dako, 1:100, clone EP1; Dako; Agilent Technologies Denmark ApS Glostrup, Denmark) and PR (Dako, 1: 100, clone PgR 1294) were used as primary antibodies. After incubation overnight at room temperature, secondary antimouse antibodies (Dako) were applied. Sections were stained with 3,3'-diaminobenzidine and counterstained with hematoxylin (Merck KGaA, Darmstadt, Germany). Finally, the sections were closed with Pertex ${ }^{\circledR}$ (Histolab Products AB, Gothenburg, Sweden). Each section had positive control (endometrial tissue) and negative internal control (colon tissue). ${ }^{8}$

\section{Statistical analysis}

Statistical analysis was performed using the SPSS version 16.0 software (SPSS Inc.,
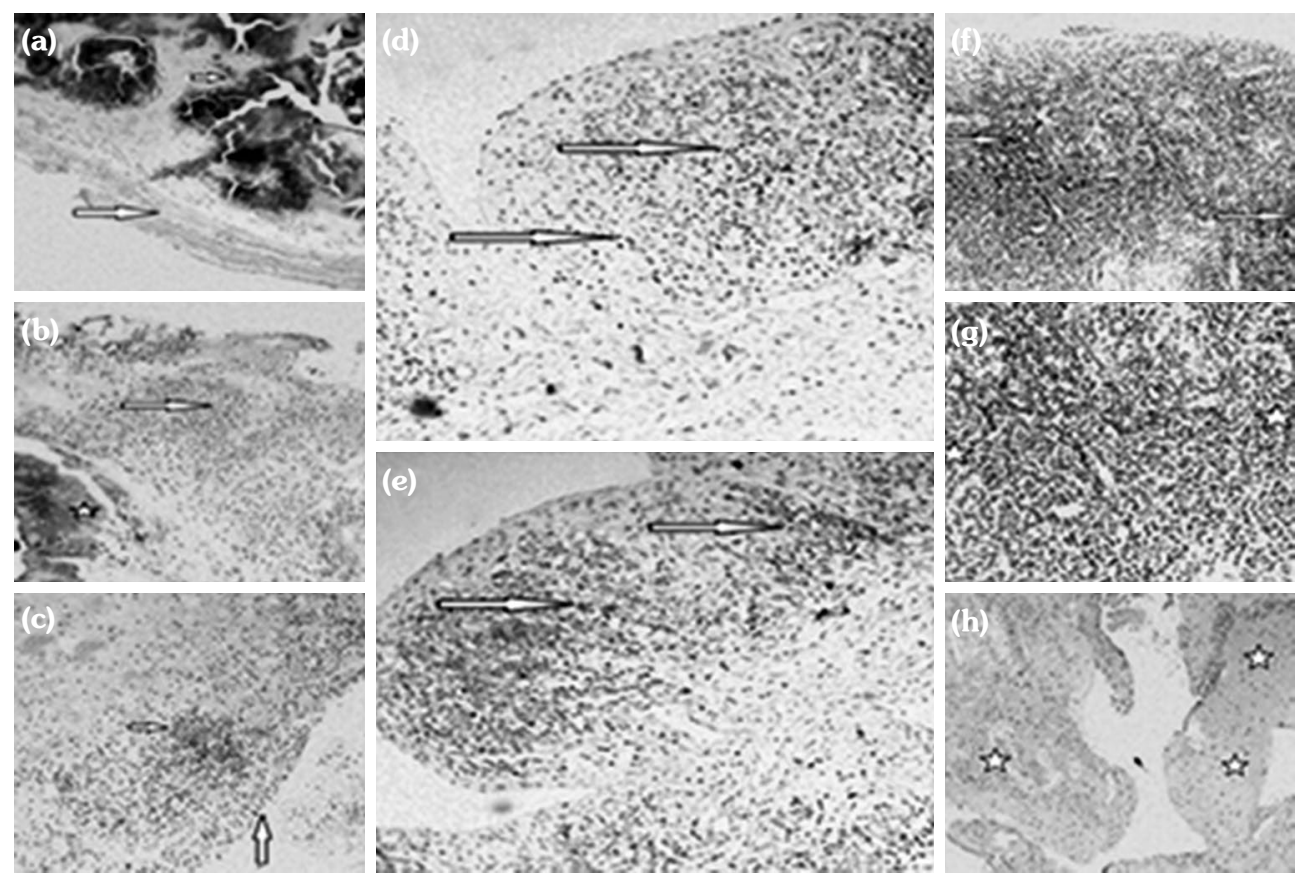

Figure 2. Examples of osteoarthritis and rheumatoid arthritis groups.

While examining osteoarthritis (OA) and rheumatoid arthritis (RA) groups, $\times 10-\times 20$ objective, hematoxylin and eosin $(\mathrm{H}-\mathrm{E})$ and immunohistochemistry (IHC) stained sections, and classical microscope were used. (a) Osteoid metaplasia (long arrow) and thickened trabeculae (short arrow) in $\mathrm{OA}(\mathrm{H}-\mathrm{E}, \times 10)$. (b) Subchondral inflammation (long arrow), and cartilage degeneration (asterisk) in OA (H-E, $\times 1)$. (c) Synoviocyte hyperplasia (long arrow) and perivascular infiltrates of lymphocytes in RA (short arrow) (H-E, $\times 10)$. (d) Progesterone receptor positivity in RA (arrows) (IHC, $\times 10)$. (e) Estrogen receptor positivity in RA (arrows) (IHC, $\times 10)$. (f) Diffuse infiltrates of lymphocytes in RA (arrows) ( $\times 10, \mathrm{H}-\mathrm{E})$. (g) Focal aggregates of lymphocytes in RA (asterisk) ( $\mathrm{H}-\mathrm{E}, \times 20)$. (h) Fibrillation in RA (asterisk) (H-E, $\times 10)$. 
Table 1. Relationship between histopathological features and rheumatoid arthritis and osteoarthritis groups

\begin{tabular}{|c|c|c|c|c|c|}
\hline & \multicolumn{2}{|c|}{ OA group ( $\mathrm{n}=92$ ) } & \multicolumn{2}{|c|}{ RA group $(n=30)$} & \multirow[b]{2}{*}{$p$} \\
\hline & $\mathrm{n}$ & $\%$ & $\mathrm{n}$ & $\%$ & \\
\hline $\begin{array}{l}\text { Sex } \\
\quad \text { Male } \\
\text { Female }\end{array}$ & $\begin{array}{l}27 \\
65\end{array}$ & $\begin{array}{l}29.3 \\
33.3\end{array}$ & $\begin{array}{l}10 \\
20\end{array}$ & $\begin{array}{l}33.3 \\
66.7\end{array}$ & 0.01* \\
\hline $\begin{array}{l}\text { Female (ER) } \\
\text { No } \\
\text { Yes }\end{array}$ & $\begin{array}{l}49 \\
16\end{array}$ & $\begin{array}{l}75.3 \\
24.7\end{array}$ & $\begin{array}{c}4 \\
16\end{array}$ & $\begin{array}{l}20.0 \\
80.0\end{array}$ & 0.01* \\
\hline $\begin{array}{l}\text { Female (PR) } \\
\text { No } \\
\text { Yes }\end{array}$ & $\begin{array}{c}6 \\
59\end{array}$ & $\begin{array}{c}9.3 \\
90.7\end{array}$ & $\begin{array}{c}14 \\
6\end{array}$ & $\begin{array}{l}70.0 \\
30.0\end{array}$ & $0.02 *$ \\
\hline $\begin{array}{l}\text { Synoviocyte hyperplasia } \\
\text { No } \\
\text { Yes }\end{array}$ & $\begin{array}{l}78 \\
14\end{array}$ & $\begin{array}{l}84.8 \\
15.2\end{array}$ & $\begin{array}{l}10 \\
20\end{array}$ & $\begin{array}{l}33.3 \\
66.7\end{array}$ & 0.01* \\
\hline $\begin{array}{l}\text { Fibrosis } \\
\text { No } \\
\text { Yes }\end{array}$ & $\begin{array}{c}83 \\
9\end{array}$ & $\begin{array}{c}90.2 \\
9.8\end{array}$ & $\begin{array}{c}6 \\
24\end{array}$ & $\begin{array}{l}20.0 \\
80.0\end{array}$ & 0.01* \\
\hline $\begin{array}{l}\text { Proliferating blood vessels } \\
\text { No } \\
\text { Yes }\end{array}$ & $\begin{array}{l}81 \\
11\end{array}$ & $\begin{array}{l}88.0 \\
12.0\end{array}$ & $\begin{array}{l}11 \\
19\end{array}$ & $\begin{array}{l}36.7 \\
63.3\end{array}$ & 0.01* \\
\hline $\begin{array}{l}\text { Focal aggregates of lymphocytes } \\
\text { No } \\
\text { Yes }\end{array}$ & $\begin{array}{c}83 \\
9\end{array}$ & $\begin{array}{c}90.2 \\
9.8\end{array}$ & $\begin{array}{c}4 \\
26\end{array}$ & $\begin{array}{l}13.3 \\
86.7\end{array}$ & 0.01* \\
\hline $\begin{array}{l}\text { Perivascular infiltrates of lymphocytes } \\
\text { No } \\
\text { Yes }\end{array}$ & $\begin{array}{l}60 \\
32\end{array}$ & $\begin{array}{l}65.2 \\
34.8\end{array}$ & $\begin{array}{c}7 \\
23\end{array}$ & $\begin{array}{l}76.2 \\
28.6\end{array}$ & 0.01* \\
\hline $\begin{array}{l}\text { Diffuse infiltrates of lymphocytes } \\
\text { No } \\
\text { Yes }\end{array}$ & $\begin{array}{l}62 \\
30\end{array}$ & $\begin{array}{l}67.4 \\
32.6\end{array}$ & $\begin{array}{c}5 \\
25\end{array}$ & $\begin{array}{l}16.7 \\
83.3\end{array}$ & 0.01* \\
\hline $\begin{array}{l}\text { Osteoid metaplasia } \\
\text { No } \\
\text { Yes }\end{array}$ & $\begin{array}{l}19 \\
73\end{array}$ & $\begin{array}{l}20.7 \\
79.3\end{array}$ & $\begin{array}{c}22 \\
8\end{array}$ & $\begin{array}{l}73.3 \\
26.7\end{array}$ & 0.01* \\
\hline $\begin{array}{l}\text { Chondroid metaplasia } \\
\text { No } \\
\text { Yes }\end{array}$ & $\begin{array}{l}13 \\
79\end{array}$ & $\begin{array}{l}14.1 \\
85.9\end{array}$ & $\begin{array}{c}23 \\
7\end{array}$ & $\begin{array}{l}76.7 \\
23.3\end{array}$ & 0.01* \\
\hline $\begin{array}{l}\text { Thickening in trabeculae } \\
\text { No } \\
\text { Yes }\end{array}$ & $\begin{array}{l}11 \\
81\end{array}$ & $\begin{array}{l}12.0 \\
88.0\end{array}$ & $\begin{array}{c}26 \\
4\end{array}$ & $\begin{array}{l}86.7 \\
13.3\end{array}$ & 0.01* \\
\hline $\begin{array}{l}\text { Fibrillation } \\
\text { No } \\
\text { Yes }\end{array}$ & $\begin{array}{l}12 \\
80\end{array}$ & $\begin{array}{l}13.0 \\
87.0\end{array}$ & $\begin{array}{c}27 \\
3\end{array}$ & $\begin{array}{c}90.0 \\
100\end{array}$ & 0.01* \\
\hline $\begin{array}{l}\text { Subchondral inflammation } \\
\text { No } \\
\text { Yes }\end{array}$ & $\begin{array}{l}10 \\
82\end{array}$ & $\begin{array}{l}10.9 \\
89.1\end{array}$ & $\begin{array}{c}24 \\
6\end{array}$ & $\begin{array}{l}20.0 \\
80.0\end{array}$ & 0.01* \\
\hline $\begin{array}{l}\text { Cartilage degeneration } \\
\text { No } \\
\text { Yes }\end{array}$ & $\begin{array}{l}12 \\
80\end{array}$ & $\begin{array}{l}13.0 \\
87.0\end{array}$ & $\begin{array}{c}26 \\
4\end{array}$ & $\begin{array}{l}86.7 \\
13.3\end{array}$ & 0.01* \\
\hline $\begin{array}{l}\text { ER } \\
\text { No } \\
\text { Yes }\end{array}$ & $\begin{array}{l}80 \\
12\end{array}$ & $\begin{array}{l}87.0 \\
13.0\end{array}$ & $\begin{array}{l}10 \\
20\end{array}$ & $\begin{array}{l}33.3 \\
66.7\end{array}$ & $0.01 *$ \\
\hline $\begin{array}{l}\text { PR } \\
\text { No } \\
\text { Yes }\end{array}$ & $\begin{array}{l}48 \\
44\end{array}$ & $\begin{array}{l}52.2 \\
47.8\end{array}$ & $\begin{array}{c}21 \\
9\end{array}$ & $\begin{array}{l}70.0 \\
30.0\end{array}$ & 0.09 \\
\hline
\end{tabular}

ER: Estrogen receptor; PR: Progesterone receptor; * Limit of significance was accepted as $p<0.05$ in Chi-square test. Significant results in statistical study were recorded in italics. 
Chicago, IL, USA). Since the groups were not distributed normally with the Kolmogorov-Smirnov test, nonparametric tests were used in statistical evaluations. Descriptive data were expressed as median (min-max), percentage, and frequency. Categorical variables were compared using the Chi-square test. RA and OA groups were evaluated by multivariate logistic regression analysis with 95\% confidence interval and 1.0 odds ratio (OR) as reference. $\mathrm{P}<0.05$ was considered statistically significant.

\section{RESULTS}

Rheumatoid arthritis and OA cases were significantly higher in the female sex, but there was no difference between the groups in terms of age.

Synoviocyte hyperplasia, fibrosis, proliferating blood vessels, focal aggregates of lymphocytes, perivascular infiltrates of lymphocytes, and diffuse infiltrates of lymphocytes were significantly higher in RA group $(p=0.01)$. Chondroid-osteoid metaplasia, fibrillation, cartilage degeneration, thickened trabeculae, and subchondral inflammation $(p=0.01)$ were significantly higher in OA group. ER and PR positivity were significantly higher in RA group $(p=0.01)$. The statistical relationship in females was similar for sex hormones $(p=0.01)$. There was no significant difference between the groups in terms of sex hormones in males. The descriptive statistical findings of these parameters were shown in Table 1 .

In the RA group, ER was significantly associated with focal aggregates of lymphocytes $(p=0.01)$, perivascular infiltrates $(p=0.03)$, and diffuse lymphocyte infiltrates $(p=0.01)$ in the Chi-square analysis. In the OA group, PR was significantly associated with subchondral inflammation in the Chi-square analysis $(p=0.01)$ (Tables 2 and 3).

In multivariate analysis, it was observed that ER was an independent risk factor for focal aggregates of lymphocytes in the RA group. Also, in the OA group, PR was an independent risk factor for subchondral inflammation $(\mathrm{OR}=3.90$ [1.28-11.80], $\mathrm{p}=0.02$ ) (Table 4).

Table 2. Relationship between sex hormones and rheumatoid arthritis

\begin{tabular}{|c|c|c|c|c|c|c|c|c|c|c|}
\hline & \multicolumn{10}{|c|}{ Rheumatoid arthritis (\%) } \\
\hline & \multicolumn{2}{|c|}{$\mathrm{ER}(+)$} & \multicolumn{2}{|c|}{ ER (-) } & \multirow{2}{*}{$\frac{95 \% \mathrm{CI}}{p}$} & \multicolumn{2}{|c|}{$\mathrm{PR}(+)$} & \multicolumn{2}{|c|}{ PR (-) } & \multirow{2}{*}{$\frac{95 \% \mathrm{Cl}}{p}$} \\
\hline & $\mathrm{n}$ & $\%$ & $\mathrm{n}$ & $\%$ & & $\mathrm{n}$ & $\%$ & $\mathrm{n}$ & $\%$ & \\
\hline Synoviocyte hyperplasia & & & & & 0.33 & & & & & 0.23 \\
\hline Yes & 15 & 75.0 & 9 & 90.0 & & 6 & 66.7 & 18 & 85,7 & \\
\hline No & 5 & 25.0 & 1 & 10.0 & & 3 & 33.3 & 3 & 14,3 & \\
\hline Fibrosis & & & & & 0.28 & & & & & 0.66 \\
\hline Yes & 12 & 60.0 & 8 & 40.0 & & 6 & 66.7 & 14 & 66.7 & \\
\hline No & 8 & 80.0 & 2 & 20.0 & & 3 & 33.3 & 7 & 33.3 & \\
\hline Proliferating blood vessels & & & & & 0.18 & & & & & 0.57 \\
\hline Yes & 11 & 55.0 & 8 & 80.0 & & 6 & 66.7 & 13 & 61.9 & \\
\hline No & 9 & 45.0 & 2 & 20.0 & & 3 & 33.3 & 8 & 38.1 & \\
\hline Focal aggregates of lymphocytes & & & & & 0.01* & & & & & 0.72 \\
\hline Yes & 18 & 90.0 & 4 & 40.0 & & 7 & 77.8 & 15 & 71.4 & \\
\hline No & 2 & 10.0 & 6 & 60.0 & & 2 & 22.2 & 6 & 28.6 & \\
\hline Perivascular infiltrates of lymphocytes & & & & & $\mathbf{0 . 0 3}^{*}$ & & & & & 0.21 \\
\hline Yes & 18 & 90.0 & 2 & 10.0 & & 8 & 88.9 & 14 & 66.7 & \\
\hline No & 5 & 50.0 & 5 & 50.0 & & 1 & 11.1 & 7 & 33.3 & \\
\hline Diffuse infiltrates of lymphocytes & & & & & $0.002^{*}$ & & & & & 0.93 \\
\hline Yes & 19 & 95.0 & 4 & 40.0 & & 7 & 77.8 & 16 & 76.2 & \\
\hline No & 1 & 5.0 & 6 & 60.0 & & 2 & 22.2 & 5 & 23.8 & \\
\hline
\end{tabular}


Table 3. Relationship between sex hormones and osteoarthritis

\begin{tabular}{|c|c|c|c|c|c|c|c|c|c|c|}
\hline & \multicolumn{10}{|c|}{ Osteoarthritis (\%) } \\
\hline & \multicolumn{2}{|c|}{ ER $(+)$} & \multicolumn{2}{|c|}{$\mathrm{ER}(-)$} & \multirow{2}{*}{$\frac{95 \% \mathrm{CI}}{p}$} & \multicolumn{2}{|c|}{$\operatorname{PR}(+)$} & \multicolumn{2}{|c|}{ PR (-) } & \multirow{2}{*}{$\frac{95 \% \mathrm{CI}}{p}$} \\
\hline & $\mathrm{n}$ & $\%$ & $\mathrm{n}$ & $\%$ & & $\mathrm{n}$ & $\%$ & $\mathrm{n}$ & $\%$ & \\
\hline Osteoid metaplasia & & & & & 0.69 & & & & & 0.63 \\
\hline Yes & 11 & 91.7 & 70 & 87.5 & & 38 & 86.4 & 43 & 89.6 & \\
\hline No & 1 & 8.3 & 10 & 12.5 & & 6 & 13.6 & 5 & 10.4 & \\
\hline Chondroid metaplasia & & & & & 0.47 & & & & & 0.47 \\
\hline Yes & 11 & 91.7 & 68 & 85.0 & & 39 & 88.6 & 40 & 83.3 & \\
\hline No & 1 & 8.3 & 12 & 15.0 & & 5 & 11.4 & 8 & 16.7 & \\
\hline Thickening in trabeculae & & & & & 0.20 & & & & & 0.60 \\
\hline Yes & 12 & 100.0 & 70 & 87.5 & & 40 & 90.9 & 42 & 87.5 & \\
\hline No & 0 & 0.0 & 10 & 12.5 & & 4 & 9.1 & 6 & 12.5 & \\
\hline Fibrillation & & & & & 0.19 & & & & & 0.87 \\
\hline Yes & 9 & 75.0 & 71 & 88.8 & & 38 & 86.4 & 42 & 87.5 & \\
\hline No & 3 & 25.0 & 9 & 11.2 & & 6 & 13.6 & 6 & 12.5 & \\
\hline Subchondral inflammation & & & & & 0.69 & & & & & 0.01* \\
\hline Yes & 9 & 75.0 & 64 & 80.0 & & 39 & 88.6 & 31 & 66.7 & \\
\hline No & 3 & 25.0 & 16 & 20.0 & & 5 & 66.7 & 16 & 13.3 & \\
\hline Cartilage degeneration & & & & & 0.60 & & & & & 0.18 \\
\hline Yes & 11 & 91.7 & 69 & 86.2 & & 35 & 79.5 & 43 & 89.5 & \\
\hline No & 1 & 8.3 & 11 & 13.8 & & 9 & 20.5 & 5 & 10.5 & \\
\hline
\end{tabular}

\section{DISCUSSION}

Rheumatoid arthritis and OA have very different properties in terms of etiopathogenesis and histopathological features. ${ }^{1,2}$ However, both diseases have important roles in etiopathogenesis and histopathology through the receptors of sex hormones. ${ }^{1-5}$ In this study, we investigated the relationship between histopathological findings and hormone receptors in RA and OA.
Rheumatoid arthritis and OA are both common in females. ${ }^{1-4}$ The peak ages of both diseases are different. ${ }^{1,2}$ In our study, the cases were more common in females, while there was no difference in terms of age. The histopathological materials examined in our study were generally obtained from cases operated for deformity. Since serious deformities require many years to develop, it may be thought that the absence of age difference between the groups in our study

Table 4. Multivariate logistic regression analysis for rheumatoid arthritis and osteoarthritis

\begin{tabular}{|c|c|c|c|c|c|c|}
\hline & \multicolumn{6}{|c|}{ Multivariate analysis } \\
\hline & \multicolumn{3}{|c|}{ ER in RA cases } & \multicolumn{3}{|c|}{$\mathrm{PR}$ in $\mathrm{OA}$ cases } \\
\hline & OR & $95 \% \mathrm{CI}$ & $p$ & OR & $95 \% \mathrm{CI}$ & $p$ \\
\hline Focal aggregates of lymphocytes & 1.51 & $1.02-2.25$ & 0.04* & - & - & - \\
\hline Perivascular infiltrates of lymphocytes & 4.30 & $0.91-1.40$ & 0.22 & - & - & - \\
\hline Diffuse infiltrates of lymphocytes & 1.31 & $0.85-2.03$ & 0.12 & - & - & - \\
\hline Subchondral inflammation & - & - & - & 5.79 & $0.85-0.77$ & 0.02* \\
\hline
\end{tabular}

ER: Estrogen receptor; RA: Rheumatoid arthritis; PR: Progesterone receptor; OA: Osteoarthritis; OR: Odds ratio; CI: Confidence interval; * Limit of significance was accepted as 0.05 . Statistically significant results were recorded in italics. 
was due to this reason. The differences observed in terms of histopathological findings in our study were consistent with the data available in the literature. $^{1-3}$

We found the presence of ER and PR higher in females with RA than females with OA. This may suggest that the role of hormone receptors is more pronounced in RA cases compared to OA in females. Estrogen stimulates humoral immunity by increasing antibody production at high or low concentrations. ${ }^{4}$ In this context, it may be thought that the presence of ER detected higher in RA cases may also be associated with an increase in antibody formation against the joint tissue. There was no difference between the OA and RA groups in terms of the presence of sex hormone receptors in males. However, the low number of male participants did not allow us to interpret these results for males.

In our study, ER was associated with focal lymphocyte aggregates, perivascular infiltration of lymphocytes, and diffuse lymphocyte infiltration in RA group. Also, the ER was an independent risk factor for focal lymphocyte aggregates in RA group. According to our results, the first change that ER made in RA could be focal lymphocyte aggregates. In patients with RA, focal lymphocytic aggregates have been reported to penetrate the cortical bone barrier and produce bone erosions. ${ }^{9}$ It may be thought that the ER contributes to bone damage through lymphocytic aggregates. Also, focal lymphocytic aggregates in the synovium have been reported to act as a secondary or ectopic lymphoid organ and trigger the autoimmune process. ${ }^{10}$ Moreover, focal lymphocytic aggregates have been reported to be associated with high disease activity. ${ }^{11}$ In addition, many cells that affect apoptosis balance, which has an important role in RA pathophysiology, are found in focal lymphocytic aggregates. ${ }^{12}$ In this context, the ER may cause more serious damage in RA patients through lymphocytic aggregates. This finding may guide the approach to patients with RA. Further studies are needed on this subject.

In the treatment of RA, anti-tumor necrosis factor (TNF) drugs act by suppressing lymphoid infiltration in the synovium. In this case, it may be considered that cellular lymphoid cell migration is suppressed in the synovium by anti-TNF therapy.
In addition, anti-TNF therapy has been reported to be ineffective in histopathological changes other than synovial hyperplasia and lymphocytic infiltration. On the other hand, synovia has not been found to react differently to different biological agents in RA patients. That is, it may be thought that anti-TNF treatment acts through lymphocytic infiltrate. ${ }^{13,14}$ In this context, the increased ER of the RA patients that we detected in our study may have contributed to the formation of lymphoid aggregates, creating a clinical and prognostic effect. Identifying the presence and subtypes of synovial sex hormone receptors in RA may contribute to treatment selection, predicting response to the drug, and predicting histopathological features and prognosis.

The relative expression of $\mathrm{ER}$ and $\mathrm{PR}$ subtypes in target cells, including the synovial tissue, according to progesterone and estrogen stimuli determines the functional response and the severity of the response. ${ }^{5}$ Two ER subtypes (ER- $\alpha$, ER- $\beta$ ) and three PR subtypes are defined (PR-A and PR-B, PR-C). In addition to blood levels of sex hormones, they also have different effects depending on the target cell and the expressed receptor subtype., ${ }^{4,5}$ Also, there may be a different ligand presence other than sex hormones that bind to PRs and ERs. In our study, we could not examine the receptor subtype. This topic needs further studies.

In our study, the ERs were not associated with histopathological findings in OA. It was also found that PRs trigger subchondral inflammation in OA. Consistent with our findings, Chien et al. ${ }^{15}$ reported that triggering subchondral inflammation increased OA findings. In this context, PRs may have increased the $\mathrm{OA}$ clinic and contributed to its exacerbation by increasing subchondral inflammation.

In our study, we found the ER and PR levels lower in OA patients. This situation is compatible with the findings of the literature. For example, studies have a suppressive effect on steroid hormone receptors on metalloproteinases that destroy the extracellular matrix, and this has been reported to have a protective effect from OA. ${ }^{16,17}$ Also, an inverse correlation has been reported between body mass index and synovial steroid receptor expressions. ${ }^{18}$ So, although sex hormones occur in adipose tissue in obese people, it is not protective due to low receptor 
expression. In addition, low serum endogenous estrogen levels in females are reported to be associated with synovitis, effusion, and other OA-related structural changes in the knee joint. ${ }^{19}$ In some studies, although sex hormones have been reported to activate mast cells in the inflammatory process, it is controversial whether mast cells have a damaging or repairing effect. ${ }^{16}$ Also, the presence of PRs in OA was found to increase subchondral inflammation. This finding is consistent with the information in the literature that PRs increase the damage of the articular cartilage by increasing macrophage activation in the synovial tissues. In addition, it was suggested that sex hormone receptors may be a new treatment target in arthritis. ${ }^{4}$

As far as we know, there is no study examining $\mathrm{OA}$ and RA patients in terms of the presence of synovial ERs, PRs, and its relationship to histopathological changes. In this context, we think that our findings, which show that the presence of sex hormone receptors is associated with histopathological changes, are important.

The limitations of our study may include the low number of participants, the absence of a control group of healthy volunteers, the inability to study receptor subtypes, the inability to detect hormone levels, and clinical and radiological markers and activation indicators.

In conclusion, the histopathology features of both RA and OA have different clinical implications on the disease courses. The sex hormone receptor's existence in synovium may change histopathological features and affect the clinical course.

\section{Declaration of conflicting interests}

The authors declared no conflicts of interest with respect to the authorship and/or publication of this article.

\section{Funding}

The authors received no financial support for the research and/or authorship of this article.

\section{REFERENCES}

1. Firestein GS, Budd RC, Gabriel SE, McInnes IB, O'Dell JR, editors. Kelley and Firestein's Textbook of Rheumatology. 9th ed. Philadelphia, Elsevier; 2016.
2. Jin X, Wang BH, Wang X, Antony B, Zhu Z, Han $W$, et al. Associations between endogenous sex hormones and MRI structural changes in patients with symptomatic knee osteoarthritis. Osteoarthritis Cartilage 2017;25:1100-6.

3. McCulloch K, McGrath S, Huesa C, Dunning L, Litherland G, Crilly A, et al. Rheumatic Disease: Protease-Activated Receptor-2 in Synovial Joint Pathobiology. Front Endocrinol (Lausanne) 2018;9:257.

4. Ortona E, Pierdominici M, Maselli A, Veroni C, Aloisi F, Shoenfeld Y. Sex-based differences in autoimmune diseases. Ann Ist Super Sanita 2016;52:205-12.

5. Martocchia A, Stefanelli M, Cola S, Falaschi P. Sex steroids in autoimmune diseases. Curr Top Med Chem 2011;11:1668-83.

6. Rooney M, Condell D, Quinlan W, Daly L, Whelan A, Feighery $\mathrm{C}$, et al. Analysis of the histologic variation of synovitis in rheumatoid arthritis. Arthritis Rheum 1988;31:956-63.

7. Gardner DL, Salter DM, Oates K. Advances in the microscopy of osteoarthritis. Microsc Res Tech 1997;37:245-70.

8. Matos LL, Trufelli DC, de Matos MG, da Silva Pinhal MA. Immunohistochemistry as an important tool in biomarkers detection and clinical practice. Biomark Insights 2010;5:9-20.

9. Jimenez-Boj E, Nöbauer-Huhmann I, Hanslik-Schnabel B, Dorotka R, Wanivenhaus AH, Kainberger F, et al. Bone erosions and bone marrow edema as defined by magnetic resonance imaging reflect true bone marrow inflammation in rheumatoid arthritis. Arthritis Rheum 2007;56:1118-24.

10. Pablos JL, Santiago B, Tsay D, Singer MS, Palao G, Galindo M, et al. A HEV-restricted sulfotransferase is expressed in rheumatoid arthritis synovium and is induced by lymphotoxin-alpha/beta and TNFalpha in cultured endothelial cells. BMC Immunol 2005;6:6

11. Veale DJ, Orr C, Fearon U. Cellular and molecular perspectives in rheumatoid arthritis. Semin Immunopathol 2017;39:343-54.

12. Dubikov AI, Kalinichenko SG. Small molecules regulating apoptosis in the synovium in rheumatoid arthritis. Scand J Rheumatol 2010;39:368-72.

13. Manca ML, Lattuada D, Valenti D, Marelli O, Corradini $\mathrm{C}$, Fernàndez-Busquets $\mathrm{X}$, et al. Potential therapeutic effect of curcumin loaded hyalurosomes against inflammatory and oxidative processes involved in the pathogenesis of rheumatoid arthritis: The use of fibroblast-like synovial cells cultured in synovial fluid. Eur J Pharm Biopharm 2019;136:84-92.

14. Hirohata S, Abe A, Murasawa A, Kanamono T, Tomita T, Yoshikawa H. Differential effects of IL-6 blockade tocilizumab and TNF inhibitors on angiogenesis in synovial tissues from patients with rheumatoid arthritis. Mod Rheumatol 2017;27:766-72. 
15. Chien SY, Tsai $\mathrm{CH}$, Liu SC, Huang $\mathrm{CC}$, Lin TH, Yang YZ, et al. Noggin Inhibits IL-1 $\beta$ and BMP-2 Expression, and Attenuates Cartilage Degeneration and Subchondral Bone Destruction in Experimental Osteoarthritis. Cells 2020;9:927.

16. Zierau O, Zenclussen AC, Jensen F. Role of female sex hormones, estradiol and progesterone, in mast cell behavior. Front Immunol 2012;3:169.

17. Wardhana, Surachmanto EE, Datau EA, Ongkowijaya J, Karema-Kaparang AM. Transdermal bio-identical progesterone cream as hormonal treatment for osteoarthritis. Acta Med Indones 2013;45:224-32.

18. Watanabe $\mathrm{H}$, Takahashi $\mathrm{K}$, Ishii $\mathrm{H}$, Iizawa N, Kawaji $\mathrm{H}$, Majima T, et al. Association between steroid hormone receptors expression in the synovium and body mass index in human osteoarthritis. Osteoarthritis and Cartilage 2016;24:S68-S9.

19. Jin X, Wang BH, Wang X, Antony B, Zhu Z, Han $W$, et al. Associations between endogenous sex hormones and MRI structural changes in patients with symptomatic knee osteoarthritis. Osteoarthritis Cartilage 2017;25:1100-6. 